\title{
Pre-Service Teachers' Knowledge and Their Beliefs Towards Inclusive Education: Implications for Teacher Education Programme
}

\author{
Olateju Oluwayemisi Ruth* \\ Okanlawon Ayoade Ejiwale** \\ Fakokunde Jubril Busuyi***
}

\begin{abstract}
Today's classrooms in Nigerian schools are witnessing heterogeneous student populations. With this current classroom nature, teachers feel generally ill-prepared and are unwilling to accommodate disadvantaged students. According to research findings, unfortunately, disadvantaged students were usually excluded during classroom instruction. Consequently, this resulted in reduced learning opportunities, stigmatization and social exclusion. Thus, this paper investigated pre-service teachers' level of knowledge about inclusive education and explored their beliefs towards inclusive education. To achieve these objectives, a descriptive study design was adopted. The sample for the study consisted of 166 pre-service science teachers who were drawn from the population of special education undergraduate students from a tertiary institution using the stratified random sampling technique. The study utilized two validated questionnaires, Teachers' Knowledge about Inclusive Education Test (TKIET), and True-False Twenty-oneItem Test and Teachers' Belief towards Inclusive Education (TBIS) which is structured on a 5-point Likert scale to elicit the information from the respondents. The data collected were analyzed using descriptive statistics. The results of the study indicated that (1) pre-service teachers had a moderate knowledge about inclusive education and (2) pre-service teachers held positive beliefs about the effectiveness of inclusive education. Major conclusions which arise from this study are that pre-service special education teachers in Nigeria had moderate knowledge about inclusive education. In spite of their moderate knowledge about inclusive education they exhibited positive beliefs about the effectiveness of inclusive education.
\end{abstract}

Keywords: disadvantage students, struggling learners, adaptive instruction, curriculum modification, inclusive education

\section{Introduction}

In recent years, student populations in Nigerian classrooms at both primary and secondary schools have been becoming progressively more heterogeneous. This is because today's classrooms comprise students with varying abilities, special needs, learning disabilities and physical challenges. Thus, it is imperative to create inclusive education settings in order to promote academic achievement and equity for all students. As reported by You, Kim and Shin (2019), the number of inclusive education settings where students with and without disabilities are educated together has been increasing worldwide over the last few decades. Creation of inclusive education settings is essential in order to establish the current practice of excluding the disadvantaged students (also known as students with disabilities) during regular classroom instruction. The acts of exclusion of

\footnotetext{
* Department of Educational Management, Osun State University, Ipetu-ljesa, Campus, Nigeria

** Department of Science, Technology and Mathematics Education, Osun State University, Ipetu-ljesa, Campus, Nigeria

*** Department of Science, Technology and Mathematics Education, Osun State University, Ipetu-ljesa, Campus, Nigeria
} 
disadvantaged students have been found to result in reduced learning opportunities, stigmatization and social exclusion (Robinson, 2017).

The developed countries in the world are currently addressing the situation by introducing inclusive education into their schools with a view to making learning contents interesting, understandable and relevant to all students regardless of their ability or background (Nilhom \& Goransson, 2017; AIMahdi \& Bukamal, 2019). According to the UNESCO definition, inclusive education refers to the ability of school to provide quality education for all children, regardless of their differences so as to learn alongside their peers who do not face similar challenges.

According to Murdaca, Oliva, and Costa (2018), inclusive education involves active modification of curriculum, pedagogy, learning environment and assessment practices in response to students' diversity. In Nigerian context, an inclusion classroom is regarded as a classroom that allows students who have diverse academic abilities, varied social status, and physical disability. Inclusive education specialists believe that inclusive education is beneficial to students both with and without disabilities within the same learning environment (Pappas, Papoulse \& Drigas, 2018). As reported by Kavale and Forness (2000), the more students without disabilities have contact with their peers with disabilities, the greater the chance they (students without disabilities) will learn tolerance and have a greater acceptance of others' differences. In expressing the benefits of inclusion to the learners with disabilities, the proponents of inclusive education claim that special needs students in regular classes do better academically and socially than comparable students in non-inclusive settings (Ajuwon, 2008).

The successful implementation of inclusive education is greatly influenced by many factors. These factors were highlighted by AIMahdi and Bukamal (2019) including the quality of teacher education programmes, teachers' pedagogical content knowledge and skills, extent of students' disability and teachers' attitudes towards inclusive education, which are strongly influenced by teachers' gender and personal beliefs. Teachers find it challenging to meet the varying needs of students with disabilities in a classroom with a diverse student population (Yada \& Hannu, 2017). They get frustrated by trying to teach a dividedly diverse group of students because they were ill-prepared to work with students with disabilities and do not have an access to appropriate instructional resources for their education (Gal, Schrenur, Engel-Yeger, 2010; Glazzard, 2011). Some research findings (Arends, 2004; Abd Rahman, Scaif, Yahya \& Abd Jalil, 2010) have revealed that teaching in an inclusion model class is just an "additional task". Without teacher preparation in special education programmes and practical understanding of what each disadvantaged learner requires as a special learning need, it is an almost impossible task to operate in an inclusive model classroom (Acquah, Tandon, \& Lempinen, 2016). Thus, meaningful knowledge of inclusive education (KIE) and adequate training in adaptive pedagogy are essential in the education of students in special learning needs. Teachers need special knowledge and skills to effectively teach diverse learners as reported by Acquah, Tandon and Lempinen (2016).

Broad-based evaluations of teacher education programmes across developing countries support the conclusion that current teacher training programmes are deficient in addressing the task of preparing future teachers for inclusive education (Haug, 2017). The problem with teaching in an inclusion model classroom is not only associated with initial teacher preparation, but also emanated from teachers' belief towards inclusive education. Beliefs are defined as statements considered to be true or false, regardless of what they are, which defines expectations as explicit cognitive predictions with various degrees of strength (Brophy \& Evertson, 1981). Research studies have shown that teachers' performance in a classroom is influenced by their beliefs about teaching and learning (Pajares, 1992). Beliefs about teaching inform pedagogical design and action (Bourdieu \& Passerons, 1990). It is particularly the belief about inclusive teaching that informs teachers' action with respect to valuing heterogeneity, adopting adaptive instructional strategies, modifying curriculum and creating adequate learning environments in response to student diversity (Ritter, Wehner, Lohaus, Kramer, 2019). 
Unfortunately, contemporary research insights into professional development of teacher trainees with regard to acquisition of knowledge and skills for inclusive education are relatively scanty. This is because the state of inclusive education in Nigeria (and many other developing countireas) is relatively at infantry stage. In other words, little is known about this subject in Nigerian Teacher Education programmes. Previous studies in the field of inclusive education tend to focus on analyzing different conceptualizations of inclusive education, learning benefits and consequences of inclusive education and teachers' attitude towards inclusive education but paying little or no attention to teacher knowledge and beliefs concerning inclusive education as determinants of success of inclusive education. Thus, this study seeks to address the following questions that are related to preservice teacher's level of knowledge and beliefs towards inclusive education:

1. What is Nigerian pre-service teachers' level of knowledge about inclusive education?

2. What are Nigerian pre-service teachers' beliefs about inclusive education during the period of training?

\section{Methodology}

A descriptive survey research design was adopted in this study. This design was used to obtain information from a sample of preservice teachers about their knowledge and beliefs towards inclusive education. The study samples were 215 third- and secondyear teacher trainees currently studying Special Education (with areas of specialization in various teaching subjects) at the Federal College of Education (Special), Oyo. All the participants were taking courses in inclusive education as part of their curriculum. Those courses were designed to get pre-service teachers to be acquainted with the demands of teaching profession and help them teach in inclusive model classrooms. The sample of pre-service teachers was drawn from Federal College of Education (Special), Oyo, using the stratified random sampling technique - specialized in Special Education/Arts, - specialized in Special Education/Social Science and - specialized in Special Education/Science.

The study utilized two questionnaires, Teachers' knowledge about Inclusive Education Test (TKIET) and Teachers' Beliefs towards Inclusive Education (TBIS) to elicit response from the study sample: TKIET, a researcher-designed instrument, consisted of 21 true-false questions in form of statements attached to three possible responses (True, False, Undecided). The third option (Undecided) was introduced to prevent guessing. The respondents were required to select a response (true or false) that shows recognition of correct or incorrect information that is presented to them. "Undecided" option is only applicable when the respondents are not sure of the correct option. The instrument (TKIET) is specifically designed to measure pre-service teachers' knowledge of inclusive education. The Teachers Beliefs towards Inclusive Education Scale (TBIS) is a slightly modified version of TBIS designed by You, Kim and Shin (2019). Simplification and introduction of some items are the major differences between the original and the modified TBIS. The modified TBIS, a 21-item questionnaire, comprised three component parts: Each component consisted of 7 items, specifically, the three component parts reflect the teachers' beliefs about the effects of inclusive education on (a) social skill development of students with disabilities, (b) cognitive ability development of students with disabilities, and (c) understanding of students with disabilities by students without disabilities. Each statement in the TBIS was measured according to a five-point Likert scale ranging from "very true of what I believe" to "very untrue of what I believe" with "neutral" as the pivotal point of the scale. Moving from "very true of what I believe" to "very untrue of what I believe", belief statements were scored from 5 to 1 . The instrument was designed to measure the extent of pre-service teachers' beliefs towards inclusive education.

A panel comprising five specialists in special education from different universities assessed the instruments for face and content validity. Panel members were selected because of their research interest in inclusive education, and several modifications were made to improve the clarity of the questionnaires based on the input from the panel. The reliability of the instrument (TKIET) 
was established using Cronbach Alpha. This yielded acceptable values of 0.75, 0.72, and 0.83 as internal coefficients of the three component parts of TKIET respectively (see table 1). The instruments were administered to the study sample with the assistance of the course and level representatives during the 2018/2019 rain semester.

Table 1 Cronbach Alpha for the three sub-scales of TKIET concerning pre-service teachers' knowledge of inclusive education

\begin{tabular}{|l|l|l|l|}
\hline S/N & Item Category & No of Item & Cronbach Alpha \\
\hline 1 & $\begin{array}{l}\text { Factor 1: Social Skill development of children with } \\
\text { disabilities }\end{array}$ & 7 & 0.75 \\
\hline 2 & $\begin{array}{l}\text { Factor 2: Cognitive Ability Development of children with } \\
\text { disabilities }\end{array}$ & 7 & 0.72 \\
\hline 3 & $\begin{array}{l}\text { Factor 3: Understanding of children with disabilities by } \\
\text { children without disabilities }\end{array}$ & 7 & 0.83 \\
\hline
\end{tabular}

The data collected were analyzed using frequency counts, percentage, mean and standard deviation. Research question 1 was resolved quantitatively by using three levels of knowledge: limited knowledge, moderate knowledge, adequate knowledge. The 21 True-False statements had a maximum score of 21. The scores within the range of 0 to 7 were considered as' little knowledge'; scores within the range of 8 to 14 were taken as 'moderate knowledge'; and scores within the range of 15 to 21 were considered as 'adequate knowledge'. In order to resolve the research question 2, criterion mean of 2.50 was set for decision making. That is, item and cluster mean of 2.50 and above indicate a positive belief about the effectiveness of inclusive education while below 2.50 indicates a negative belief about the effectiveness of inclusive education.

\section{Findings}

For clarity, the results' section was organized in accordance with the research questions. Also, relevant to the research questions data are presented in tables.

\section{Responses to the Research Questions}

Research Question 1: What is the pre-service special education teachers' level of knowledge about inclusive education?

Table 2 provides the summary of the pre-service special education teachers' level of knowledge about inclusive education on the basis of study subjects' background variables such as teaching subject, gender and study level. This summary provides the answer to research question 1.

Table $\mathbf{2}$ Level of knowledge of pre-service special education teachers about inclusive education

\begin{tabular}{|c|c|c|c|c|c|c|c|c|}
\hline \multirow[t]{2}{*}{ Variable } & \multirow[t]{2}{*}{ Category } & & \multicolumn{2}{|c|}{ Limited knowledge } & \multicolumn{2}{|c|}{$\begin{array}{l}\text { Moderate } \\
\text { knowledge }\end{array}$} & \multicolumn{2}{|c|}{$\begin{array}{l}\text { Adequate } \\
\text { knowledge }\end{array}$} \\
\hline & & & $\mathrm{N}$ & $\%$ & $\mathrm{~N}$ & $\%$ & $\mathrm{~N}$ & $\%$ \\
\hline \multirow{4}{*}{$\begin{array}{l}\text { Teaching } \\
\text { Subject }\end{array}$} & Social Science/ Commercial & (15) & 3 & 33.3 & 11 & 73.3 & 1 & 6.7 \\
\hline & Science & (66) & 7 & 10.6 & 47 & 71.2 & 12 & 18.2 \\
\hline & Arts & (85) & 4 & 4.7 & 69 & 81.2 & 12 & 14.1 \\
\hline & Total & (166) & 14 & 8.4 & 127 & 76.5 & 25 & 15.0 \\
\hline \multirow[t]{3}{*}{ Gender } & Male & (45) & 7 & 15.6 & 31 & 68.9 & 7 & 15.6 \\
\hline & Female & (121) & 7 & 5.8 & 96 & 79.3 & 18 & 14.9 \\
\hline & Total & (166) & 14 & 8.4 & 127 & 76.5 & 25 & 15.1 \\
\hline \multirow[t]{2}{*}{ Study Level } & 200 & (38) & 2 & 5.3 & 31 & 81.6 & 5 & 13.1 \\
\hline & 300 & (128) & 12 & 9.4 & 96 & 75.0 & 20 & 15.6 \\
\hline
\end{tabular}




\begin{tabular}{|l|ll|l|l|l|l|l|l|}
\hline & Total & $(166)$ & 14 & 8.4 & 127 & 76.5 & 25 & 15.0 \\
\hline
\end{tabular}

Table 2 revealed that $10.6 \%$ of the pre-service teachers specializing in special education/science have limited knowledge about inclusive education, $71.2 \%$ of them have moderate one and $18.2 \%$ of them have adequate one. $4.7 \%$ of the pre-service teachers whose area of specialization is special education/arts have limited knowledge about inclusive education, $81.2 \%$ of them have moderate one and $14.1 \%$ of them have adequate one. $33.3 \%$ of the pre-service teachers whose area of specialization is in special education/social and commercial science have limited one, $73.3 \%$ of them have moderate one, while $6.7 \%$ of them have adequate knowledge about inclusive education.

Table 2 also showed that $15.6 \%$ of the male pre-service teachers have limited knowledge about inclusive education, $68.9 \%$ of them have moderate one, while $15.6 \%$ of them have adequate one. On the other hand, $5.8 \%$ of the female pre-service teachers have little knowledge about inclusive education, $79.3 \%$ of them have moderate one, while $14.9 \%$ of them have adequate one.

As could be seen from Table 2, 5.3\% of the 200 study level pre-service teachers have little knowledge about inclusive education, $81.6 \%$ of them have moderate one, while $13.1 \%$ of them have adequate one. On the other hand, $9.4 \%$ of the 300 study level pre-service teachers have little knowledge about inclusive education, $75.0 \%$ of them have moderate one and $15.6 \%$ of them have adequate one.

The average performance of the pre-service teachers on true-false statements which was used to measure their knowledge about inclusive education gives a clear indication of possession of moderate knowledge. As could be seen from Table $2,76.5 \%$ of the study sample has moderate knowledge about inclusive education.

Table 3 True-False inclusive education statements most frequently answered correctly and incorrectly by the pre-service special education teachers

\begin{tabular}{|c|l|l|l|l|l|}
\hline \multicolumn{2}{|c|}{ Correctly answered statements } & \multicolumn{3}{|c|}{ Incorrectly answered statements } \\
\hline $\begin{array}{c}\text { Statement } \\
\text { Number }\end{array}$ & Statement & $\begin{array}{l}\text { Statement } \\
\text { Number }\end{array}$ & Statement & $\begin{array}{l}\text { (\%) } \\
\text { when students of diverse abilities } \\
\text { and backgrounds play, socialize, } \\
\text { and learn together }\end{array}$ \\
\hline 2 & $\begin{array}{l}\text { Inclusive curriculum allows } \\
\text { adapting the curriculum to the } \\
\text { learning styles of children with } \\
\text { special educational needs }\end{array}$ & 82.5 & 21 & $\begin{array}{l}\text { Accommodation involves altering } \\
\text { or lowering standards in } \\
\text { instructional level in an inclusive } \\
\text { setting } \\
\text { Inclusive education involves } \\
\text { changing the child to fit the } \\
\text { system rather than changing the } \\
\text { system to fit the child }\end{array}$ & 89.2 \\
\hline
\end{tabular}


7

Students with learning difficulties need their own practice opportunities rather than watching other non-disabled students provides answers.

Differentiated classroom should include areas in which students can work quietly as well as collaborate with others.

Children with intellectual impairment often learn very well in certain areas, or at certain stages in their life.

8

Inclusion is a catalyst for overcoming "the barriers that inhibit children's choices and ability to achieve their full potential".

Scaffolding, flexible grouping and varying the length of time for student to master content are examples of instruction differentiations

The foremost aim of inclusive education is to end all forms of discrimination and foster socia unity

\begin{tabular}{|c|c|c|c|}
\hline 81.9 & 14 & $\begin{array}{l}\text { Summative assessments help } \\
\text { identify a student's specific } \\
\text { strengths and weaknesses for the } \\
\text { purpose of planning instruction } \\
\text { and identifying appropriate } \\
\text { interventions }\end{array}$ & 71.7 \\
\hline 71.1 & 19 & $\begin{array}{l}\text { Many disabled children have no } \\
\text { problem with learning but } \\
\text { experience difficulty in getting } \\
\text { access to classroom. }\end{array}$ & 71.1 \\
\hline 69.3 & 4 & $\begin{array}{l}\text { Inclusion means making the } \\
\text { advantaged students have } \\
\text { physical access to schools only. }\end{array}$ & 69.6 \\
\hline 69.3 & 1 & $\begin{array}{l}\text { In an inclusive setting, every } \\
\text { disadvantaged student feels } \\
\text { insecure and marginalized }\end{array}$ & 68.1 \\
\hline 68.7 & 6 & $\begin{array}{l}\text { Inclusive systems are } \\
\text { impediments in changing } \\
\text { discriminatory attitudes }\end{array}$ & 68.1 \\
\hline 68.1 & 16 & $\begin{array}{l}\text { Providing tape recorded versions } \\
\text { of material is an adequate } \\
\text { intervention to assist students } \\
\text { that have difficulty finding the } \\
\text { main idea in a text. }\end{array}$ & 68.1 \\
\hline 65.1 & 5 & $\begin{array}{l}\text { Inclusion in education involves } \\
\text { viewing differences between } \\
\text { students as problems to be } \\
\text { overcome rather than as } \\
\text { resources to support learning. }\end{array}$ & \\
\hline \multirow[t]{2}{*}{62.0} & 13 & $\begin{array}{l}\text { Decreasing the frequency or } \\
\text { length of invention can improve } \\
\text { outcomes for struggling } \\
\text { students. }\end{array}$ & 53.0 \\
\hline & 9 & $\begin{array}{l}\text { The basic principle of inclusive } \\
\text { education is that traditional } \\
\text { marginalized groups should be } \\
\text { separately catered for. }\end{array}$ & 48.2 \\
\hline
\end{tabular}

Table 3 provides a sample list of true-false inclusive education statements most frequently answered correctly and incorrectly by the pre-service teachers. The item-by-item analysis of the responses of the respondents revealed that the most frequently correctly answered question was item 2, "respect and understanding grow when students of diverse abilities and 
background play, socialize, and learn together", which was answered correctly by $85.5 \%$ of the respondents. Another frequently correctly answered question was item 3: "inclusive curriculum allows adapting the curriculum to the learning styles of children with special educational need". $82.5 \%$ of the respondents answered this item correctly.

Similarly, Table 3 revealed that the most frequently incorrectly answered question was item 11:"accommodation involves altering or lowering standards in instructional level in an inclusive setting". 92.4\% of the respondents answered this item incorrectly. Another example of frequently incorrect answer was given to item 21, "inclusive education involves changing the child to fit the system rather than changing the system to fit the child."

Research Question 2: What are the pre-service teachers' beliefs about inclusive education during the period of training?

Tables 4 reveals the results of analysis which provide answers to research question 2.

Table 4 Mean and standard deviation of pre-service special education teachers' beliefs about inclusive education

\begin{tabular}{|c|c|c|}
\hline Statement & \multirow[t]{2}{*}{ Mean } & \multirow[t]{2}{*}{ STD } \\
\hline Factor I: Social Skill development of children with disabilities & & \\
\hline $\begin{array}{l}\text { Children with disabilities are inclined to participate in social play activities through inclusive } \\
\text { education }\end{array}$ & 4.32 & 0.94 \\
\hline $\begin{array}{l}\text { Greater academic expectations are put on students with disabilities at the expense of their social } \\
\text { skills development }(\mathrm{N}) \text {. }\end{array}$ & 3.79 & 1.22 \\
\hline $\begin{array}{l}\text { The children with disabilities interact with children without disabilities and improve their social } \\
\text { communication skills }\end{array}$ & 4.39 & 0.98 \\
\hline $\begin{array}{l}\text { Through inclusive education, children with disabilities are likely to become better integrated in the } \\
\text { classroom }\end{array}$ & 4.05 & 1.15 \\
\hline $\begin{array}{l}\text { Through inclusive education, children with disabilities are likely to have an opportunity to think } \\
\text { about the mood of others. }\end{array}$ & 4.04 & 1.17 \\
\hline $\begin{array}{l}\text { The experience of various human relationships through inclusive education positively influence } \\
\text { overall social development }\end{array}$ & 3.81 & 1.31 \\
\hline In inclusive education, children with disabilities are more likely to be unfit or bullied (N) & 3.35 & 1.38 \\
\hline Cluster mean & 3.96 & \\
\hline \multicolumn{3}{|l|}{ Factor2: Cognitive Ability Development of children with disabilities } \\
\hline $\begin{array}{l}\text { The demonstration of appropriate responses and activities of children without disabilities have been } \\
\text { a stimulant for promoting the cognitive learning children with disabilities. }\end{array}$ & 4.33 & 1.01 \\
\hline $\begin{array}{l}\text { In inclusive education, children with disabilities are more likely to lag behind because they do not } \\
\text { have adequate learning guidance }\end{array}$ & 3.73 & 1.41 \\
\hline Through inclusive education, children are able to challenge and participate in learning & 4.01 & 1.28 \\
\hline $\begin{array}{l}\text { Adaptive behaviour learning of children with disabilities is improved through proper response and } \\
\text { demonstration of children without disabilities in inclusive education }\end{array}$ & 3.81 & 1.31 \\
\hline Through inclusive education, children with disabilities have improved mimicking skills. & 3.69 & 1.29 \\
\hline $\begin{array}{l}\text { I believe that inclusive education can significantly affect the cognitive abilities of children with } \\
\text { disabilities. }\end{array}$ & 3.48 & 1.42 \\
\hline $\begin{array}{l}\text { Inclusive education benefits students with disabilities less on academic themes than on social one } \\
\text { (N). }\end{array}$ & 3.75 & 1.39 \\
\hline Cluster mean & 3.83 & \\
\hline \multicolumn{3}{|l|}{ Factor 3: Understanding of children with disabilities by children without disabilities } \\
\hline $\begin{array}{l}\text { Through inclusive education, children without disabilities have less prejudice and rejection of } \\
\text { children with disabilities. }\end{array}$ & 3.94 & 1.34 \\
\hline $\begin{array}{l}\text { Through inclusive education, children without disabilities improve their understanding of the } \\
\text { difficulties faced by children with disabilities and their attitudes to care for others. }\end{array}$ & 4.01 & 1.22 \\
\hline
\end{tabular}




\begin{tabular}{|l|l|l|}
\hline $\begin{array}{l}\text { In the classroom, children without disabilities can support those children with disabilities have } \\
\text { suffering with discomfort }\end{array}$ & 3.99 & 1.21 \\
\hline $\begin{array}{l}\text { Inclusive education has helped children with disabilities and has improved the cooperative play } \\
\text { activities }\end{array}$ & 4.12 & 1.16 \\
\hline $\begin{array}{l}\text { Children without disabilities are more likely to mimic the undesirable behaviour of children with } \\
\text { disabilities (N). }\end{array}$ & 3.58 & 1.36 \\
\hline $\begin{array}{l}\text { Through interactions with children with disabilities, children without disabilities have gained positive } \\
\text { results in leadership }\end{array}$ & 4.12 & 1.26 \\
\hline $\begin{array}{l}\text { Inclusive classroom sometimes produces undesirable achievement outcomes for students with } \\
\text { disabilities (N). }\end{array}$ & 3.59 & 1.41 \\
\hline Cluster mean & $\mathbf{3 . 9 1}$ & \\
\hline
\end{tabular}

Table 4 presents a list of the 21 items categorized into three domains: (1) Social Skill development of students with disabilities; (2) Cognitive Ability Development of children with disabilities (3) Understanding of children with disabilities by children without disabilities. These statements on effectiveness of inclusive education were attached to the mean values indicating special education pre-service teachers' extent of belief about each statement. The first domain concerning teachers' beliefs about positive effect of inclusive education on the cognitive development of children with disabilities had a value of 3.96. The second domain relating to the teachers belief about the positive effect of inclusive education on the cognitive ability development of children with disabilities had a cluster value of 3.83 . The third domain dealing with the teachers' beliefs about the positive effects of inclusive education on understanding of peers with disabilities by children without disabilities had a cluster of value of 3.91. With these cluster values $(3.96,3.83,3.91)$, it can be concluded that the pre-service teachers held positive beliefs about the effectiveness of inclusive education. There were three areas where pre-service teachers have shown a strong belief in the effectiveness of inclusive education. These are (1) The children with disabilities interact with children without disabilities and improve their social communication skills (4.39), (2) The demonstration of appropriate responses and activities of children without disabilities have been a stimulant for promoting the cognitive learning children with disabilities (4.33), and (3) Through interactions with children with disabilities, children without disabilities have gained positive results in leadership (4.12).

\section{Discussion}

The current study basically investigated the pre-service special education teachers' level of knowledge about inclusive education and whether they held positive or negative beliefs about the effectiveness of inclusive education. The results revealed that the pre-service special education teachers had moderate knowledge about inclusive education. This finding is similar to those of others (Goddard \& Evans, 2018; Hemmings \& Woodcock, 2011; Woodcock, Hemmings \& Kay, 2012) who reported that teachers were inadequately prepared to teach in inclusive settings and, hence, they experienced difficulties in catering for student diversity in ability, ethnicity, gender, social class, culture and religion. They suggested upgrading the skills and knowledge of teachers through revising teacher education curriculum to accommodate teaching of students with special learning needs.

The fact that the pre-service teachers had moderate knowledge of inclusive education suggests that there is some gap in knowledge to be filled with regard to dealing with diverse groups of students in classrooms. With recent innovations in the teaching/learning process, teaching is no longer conceived as a linear process of transmitting knowledge from teachers to students or from online or library instructional resources to leaners. Rather, teaching requires teachers to be increasingly efficient and effective in enabling diverse groups of students to learn even more complex content and develop a wider range of skills. Unarguably, today's school teachers must be adequately prepared to teach the diverse population of students. To be able to let all students have equal opportunities, teachers' possession of pedagogical content knowledge (PCK) is required. In other words, 
teachers need an understanding of how particular subjects or topics are to be repackaged, reorganized, and adapted, according to the diverse interests and abilities of leaners.

Another finding of this study was that the pre-service teachers held positive beliefs about the effectiveness of inclusive education. This finding is compatible with studies pointing out that teachers' acceptance of the policy of inclusion has a direct influence on their attitudes towards inclusive education (Smith \& Tyler, 2011; Hopkins, Round, \& Barley, 2018), thereby affecting their commitment to implement it. With the pre-service teachers demonstration of positive beliefs about the effect of inclusive education on the social skill development of children with disabilities and their cognitive ability development, as well as the understanding of their peers with disabilities by children without disabilities, it is certain that positive beliefs about inclusive education should be pre-requisite for the pre-service teachers in order to successfully operate in a classroom populated with leaners of diverse interests and abilities. Those beliefs about inclusive education have to be addressed during the teacher training period when one realizes the potential large impact of teachers' beliefs on the successful implementation of inclusive education. Teachers tend to operate hypotheses about the learning process of their students and the necessary (individual) support on the bases of their beliefs. In other words, beliefs constitute a component part of teachers' knowledge base which strongly influences their commitment to implement inclusive education.

\section{Conclusion and Recommendations}

Major conclusions which arise from this study are that pre-service special education teachers in Nigeria had moderate knowledge about inclusive education. In spite of their moderate knowledge about inclusive education they exhibited positive beliefs about the effectiveness of inclusive education

Taking the results of this study into account, several recommendations can be made which can guide the Ministry of Education and the Teaching Service Commission (TESCOM) in equipping pre-service teachers with necessary skills and knowledge for improving the learning of diverse students and expanding their positive beliefs towards dealing with children with disabilities. Recommendations can be also made for pre-service teachers who are expected to be motivated towards advancing their knowledge of diverse leaners. Some of these recommendations are:

1. Ministry of Education (MOE) in collaboration with the Teaching Service Commission (TESCOM) should make concerted efforts to offer special training for teachers with a view to improving their inclusive classroom practices beliefs towards expanding their positive beliefs towards inclusive education

2. Nigerian Education Research and Development Council (NERDC) and Ministry of Education should make concerted efforts to make adaption and accommodations to the existing teacher education curriculum, instructional strategies and assessment procedure to reflect inclusive education practices. This action is expected to assist teachers to operate successfully in classroom populated with students of diverse learning needs.

3. Concerted efforts should be made by the pre-service and in service teachers to update their knowledge of inclusive education. One way of achieving this is through sourcing for learning and instructional materials where ingredient for implementation of inclusive education can be obtained. 


\section{References}

Abd Rahman, F., Scaife, J., Yahya, N. A., \& Ab Jalil, H. (2010). Knowledge of diverse learners: Implications for the practice of teaching. International Journal of Instruction, 3 (2), 83-96.

Acquah, E.O., Tandon, M., \&Lempinen, S. (2016). Teacher diversity awareness in the context of changing demographics. European Educational Research Journal, 15 (2), 218 -235.

Ajuwon, P.M. (2008). Inclusive education for students with disabilities in Nigeria. Benefits, Challenges and Policy Implications. International Journal of Special Education, 23, $11-16$.

AlMahdi, O. \& Bukamal, H. (2019). Pre-service teachers' attitudes toward inclusive education during their studies in Bahrain Teachers College. SAGE Open, July - September, 2019, 1 - 14, DOI: 10.1177/215812 44019865772.

Arends, R.I. (2004). Learning to Teach (6th Ed.). New York: McGraw-Hill.

Bourdieu, P. \& Passeron, J. C. (1990). Reproduction in Education, Society and Culture. Thousand Oaks, CA: SAGE Publications.

Brophy, J.E. \& Evertson, C.M. (1981). Student Characteristics and Teaching. White Plains, NY: Longman.

Gal, E., Schreur, N. \& Engel-Yeger, B. (2010). Inclusion of children with disabilities: Teachers' attitudes and requirements for environmental accommodations. International Journal of Special Education, 25, 89 - 99.

Glazzard, J. (2011). Perceptions of barriers to effective inclusion in one primary school: voices of teachers and teaching assistants. Support for Learning, 26, $56-63$.

Goddard, C. \& Evans, D. (2018). Primary pre-service teacher' attitudes towards inclusion across the training years. Australian Journal of Teacher Education, 43 (6), 122-142.

Haug, P. (2017). Understanding inclusive education: Ideals and reality. Scandinavian Journal of Disability Research, 19, $206-217$.

Hemmings, B. \& Woodcock, S. (2011). Pre-service teachers' news of inclusive education: A content analysis. Australasian Journal of Special Education, 35 (2), 103-116.

Hopkins, S., Round, P., \& Barley, K. (2018). Preparing beginning teachers for inclusion designing and assessing supplementary fieldwork experiences. Teachers and Teaching, 24, 915-930.

Kavale, K. \& Forness, S. (2000). History, rhetoric, and reality: Analysis of the inclusion debate. Remedial and Special Education, 21, $279-296$.

Murdaca, A., Oliva, P., \& Costa, S. (2018). Evaluating the perception of disability and the inclusive education of teaches: The Italian Validation of the SACIE - R (Sentiments, Attitudes and Concerns about Inclusive Education - Revised Scale). European Journal of Special Needs Education, 33, 148 - 156.

Nilhom, C. \& Goransson, K. (2017). What is meant by inclusion? An analysis of European and North American Journal articles with high impact. European Journal of Special Needs Education, 32, 437 - 451. DOI: 10.1080/08856257. 2017. 1295638

Pajares, M. F. (1992). Teachers' Beliefs and Educational Research: Cleaning up a Messy Construct. Review of Educational Research, 62 (3), 307-332.

Pappas, M.A., Papoutsi, C., \& Drigas, A.S. (2018). Policies, practices, and attitudes toward inclusive education: The case of Greece. Social Sciences, 7, 90. DOI: 10.3390/socsci 7060090 
Ritter, R., Wehner, A., Lohaus, G., \& Kramer, P. (2019). Pre-service teachers' beliefs about inclusive education before and after multi-compared to mono-educational co-teaching: An exploratory study. Frontiers in Education, 4:101. DOI: 10.3389/fedue. 2019.00101.

Robinson, D. (2017). Effective inclusive teacher education for special educational needs and disabilities: Some more thoughts on the way forward. Teaching and Teacher Education, 61, 164 - 178.

Smith, D.D. \& Tyler, N.C. (2011). Effective inclusive education: Equipping education professionals with necessary skills and knowledge. Prospects, 41, 323-339.

Woodcock, S., Hemmings, B., \& Kay, R. (2012). Does study of an inclusive education subject influence pre-service teachers' concerns and self-efficacy about inclusion? Australian Journal of Teacher Education, 37, (6), 1-11.

Yada, A. \& Hannu, S. (2017). Japanese in-service teachers' attitudes towards inclusive education and self-efficacy for inclusive practices. Teaching and Teacher Education, 64, 222 - 229.

You, S., Kim, E.K., \& Shin, K. (2019). Teachers' belief and efficacy towards inclusive education in early childhood settings in Korea. Sustainability, 11, 1489-1501. DOI: 10.3390/su11051489. 